\title{
Den store imitator - én alene eller én av flere?
}

\author{
Syfilis er ofte blitt omtalt som «den store imitator» fordi sykdommen kan ha mange uspesifikke symptomer. \\ Imidlertid er begrepet i årenes forløp blitt brukt om en rekke ulike sykdommer. Vi foreslår derfor at man \\ ved imitatortilstander heller bruker uttrykket «en stor imitator».
}

Mange tror at den kanadiske koryfeen sir William Osler (1849-1919) var den første til å omtale syfilis som «den store imitator». Nærmere undersøkelser har vist at dette sannsynligvis ikke stemmer. Det var trolig den engelske kirurgen sir Jonathan Hutchinson (1828-1913) som brukte imitatorbegrepet om syfilis første gang, i 1879 $(1-3)$.

Tidlig i den kliniske delen av medisinstudiet ble vi introdusert for begrepet «den store imitator» under en forelesning om nyrekreft. Vi antok da, med bakgrunn i begrepets natur, at dette skulle være den eneste sykdommen som hadde det aktuelle tilnavnet. Senere i studiet opplevde vi derimot at tittelen ikke var forbeholdt nyrekreft. Ikke på langt nær.

En nettordbok definerer «den store imitator» som en uspesifikk betegnelse brukt om en medisinsk tilstand som er vanskelig å diagnostisere på grunn av dens polymorfe presentasjon (4). Den store imitator er med andre ord en sykdom eller tilstand hvis differensialdiagnoser er tallrike. Et systematisk PubMed-søk med søkeordet «the great imitator» avslører at syfilis troner som den «største» imitatortilstanden. Likevel fremkommer et betydelig antall store imitatorer i tillegg til syfilis, selv om bruken av imitatorbegrepet riktignok varierer i hyp- pighet etter hvilken tilstand begrepet henspiller på (fig 1).

\section{Begrepsstruktur}

Imitatorbegrepet forekommer hovedsakelig i formene «den store imitator» og «en stor imitator», formulert med henholdsvis personlig pronomen og ubestemt artikkel, som i begge tilfeller etterfølges av et samsvarsbøyd adjektiv som beskriver substantivet. Når uttrykket er formulert med personlig pronomen (den), er det underforstått at begrepet peker på én bestemt sykdom eller tilstand. Om begrepet derimot formuleres med ubestemt artikkel (en), er det åpent for at begrepet kan brukes om flere sykdommer eller tilstander. PubMed gir 122 treff både med «the great imitator» og «a great imitator» som søkeord, noe som indikerer at søkemotoren ikke diskriminerer mellom de to ulike formene.

Som en kuriositet kan man også merke seg begrepet «den lille imitator», som trolig ble tatt i bruk for første gang av Jan Waldenström i 1937 i en omtale av porfyri. Siden syfilis da var kjent som «den store imitator», beskrev Waldenström porfyri som «den lille imitator» (5). Sammenliknet med «den store imitator» ser det ut til at «den lille imitator» i større grad er forbeholdt én bestemt diagnose, selv om

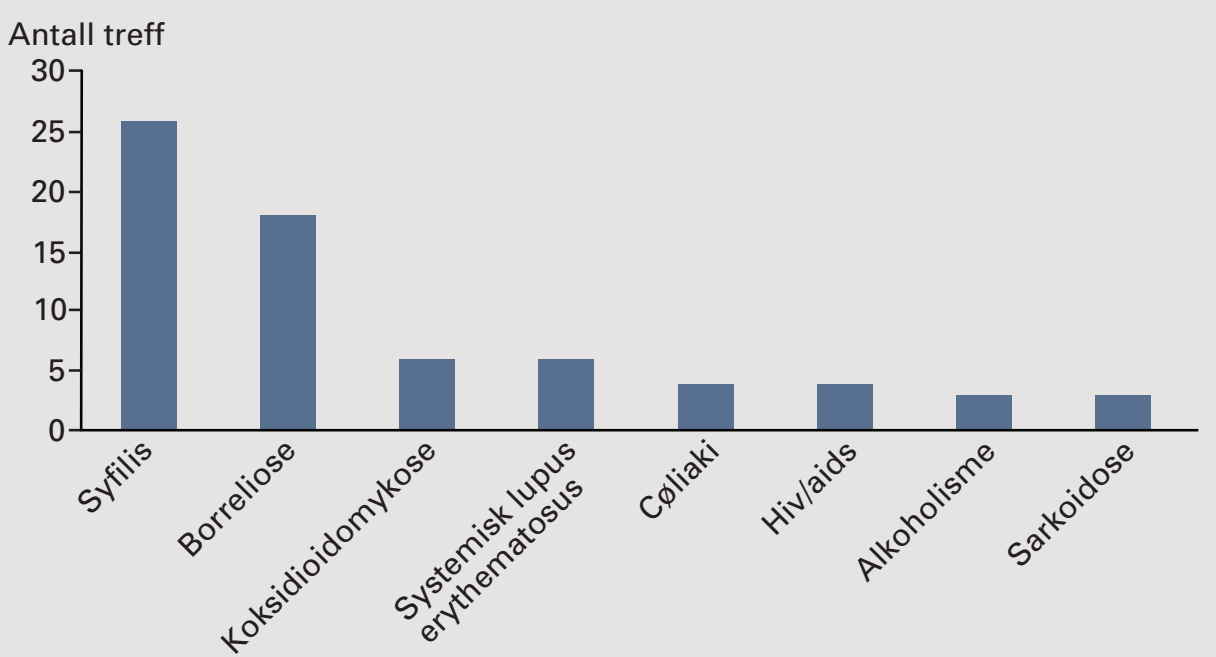

Figur 1 PubMed gir 122 treff ved søk på «the great imitator». Selv om nærmere 50 diagnoser er omtalt blant treffene, har vi for enkelhets skyld kun inkludert diagnoser som omtales som imitatortilstander i tre eller flere av totalt antall treff begrepet samtidig er vesentlig mindre brukt.

\section{Endringsforslag}

Begrepet «den store imitator» synes å ha blitt en imitator per se, og uspesifikk bruk av det har ført til begrepsinflasjon.

Å omtale en gitt sykdom som «den store imitator» er dermed uhensiktsmessig og til mer forvirring enn nytte. Vi mener formulering med ubestemt artikkel heller enn personlig pronomen gjør begrepet mer nøkternt og anvendelig. «En stor imitator» gir nemlig ikke uttrykk for å omtale kun én bestemt sykdom og vil dermed være bedre egnet til å bli brukt slik «den store imitator» brukes - tilsynelatende ubetenksomt i dag. Ettersom det i dagens medisin foreligger flerfoldige sykdommer som opptrer som imitatortilstander, foreslår vi at betegnelsen «den store imitator» bør avløses av «en stor imitator».

\section{Eirik Madsen}

eirik.madsen@student.uib.no

\section{Marius Kalsås Worren}

Eirik Madsen (f. 1987) er medisinstudent ved Universitetet i Bergen og har fra høsten 2008 fulgt forskerlinjeprogrammet ved Det medisinsk-odontologiske fakultet med et prosjekt om regulering av AMPA-reseptorer i netthinnen ved diabetes.

Marius Kalsås Worren (f. 1988) er medisinstudent ved Universitetet i Bergen og har fra høsten 2008 fulgt forskerlinjeprogrammet ved Det medisinsk-odontologiske fakultet med et prosjekt om barn med AD/HD undersøkt ved EEG.

Litteratur

1. Jackson R. Jonathan Hutchinson on syphilis. Sex Transm Dis 1980; 7: 90-6.

2. Jackson R. Letter: The great imitator. Can Med Assoc J 1976; 115: 19-20.

3. Meyerhoff E. Letter: The great imitator. Can Med Assoc J 1976; 114: 503.

4. The free dictionary. The great imitator http://medical-dictionary.thefreedictionary.com/ great+imitator (5.4.2011).

5. Waldenström J. Studien über Porphyrie. Acta Med Scand Suppl 1937: 82: 1-254. 